\title{
Safflower genotypes submitted to soil density levels
}

Edna Maria Bonfim-Silva*, Juliana Tertezinha Sasso Paludo, Tonny José Araújo da Silva, William Fenner, Maurício Dutra Zanotto

\begin{abstract}
It is essential to have knowledge of changes in soil structure, as a result of agricultural use and its relationship with crop development, especially those with potential for use in new regions, such as the cultivation of safflower (Carthamus tinctorius L.) in the Cerrado. In view of this dynamics, the objective was to evaluate the phytometric components of safflower genotypes submitted to levels of soil densities in Cerrado Oxisol. Ten safflower genotypes were then submitted to compaction (five densities: $1.0,1,2,1.4$, and $1.8 \mathrm{Mg} \mathrm{m}^{-3}$ ) in a completely randomized design with four replications under greenhouse conditions. The plots consisted of an overlap of three rings of polyvinylidene chloride of $0.01 \mathrm{~m}$ height each, and the treatments were applied in the intermediate layer. The phytometric components (plant height, number of leaves and stem diameter) and shoot dry mass of the crop were evaluated at 30, 60 and 90 days after sowing. There was no significant interaction between safflower genotypes and soil densities, with the effects being isolated for genotypes and/or densities when significant. For the phytometric characteristics evaluated, the genotypes PI250196, PI301049, PI305173, and PI305205 are more stable about the variations of soil density in comparison to the others. The phytometric components and dry mass of safflower shoot are impaired from the mean density of $1.2 \mathrm{Mg} \mathrm{m}^{-3}$.
\end{abstract}

Keywords: Carthamus tinctorius L., soil compaction, soil physics, water availability, nutrient absorption, soil structure

\section{Introduction}

The pressure exerted on the soil either

by anthropic or natural action results in the rearrangement and compaction of soil particles. This, when in excess, causes physical-hydrological impediments to proper root development (Reichert et al., 2009), destroys the plant's sustenance, aeration, reducing the availability of water, as well as the absorption of nutrients (Lima et al., 2007; Obour et al., 2017). This recurrent dynamics in the current agricultural systems is known as soil compaction.

Soil compaction can be observed visually by observing morphological deformations in the plant root system and by analyzing soil attributes, such as soil density, penetration resistance and optimum water interval that correlate with compaction (Lima et al., 2007; Reinert et al., 2008).

The range of soil density restrictive to plant growth and development is variable and dependent on several factors. The morphology of the root system, the plant species, and the cultivars present specific responses to changes in soil density. Thus, it is fundamental to study the response of each crop to soil compaction, especially in the highly mechanized agricultural scenario, in which the need to perform agricultural operations due to weather conditions contrasts with the ideal working moisture range, to the 
detriment of the soil physical quality (Genro Junior et al., 2004).

The compacted soil layer varies according to the condition to which it is subjected, agricultural operation and the water content during the same period. Research indicates that restrictive impediments to plant growth from 0.03 to $0.30 \mathrm{~m}$ depth, can be found in the general agricultural production system (Genro Junior et al., 2004; Reinert et al., 2008; Freddi et al., 2009) and the possibility of compaction increases with successive agricultural operations (Sivarajan et al., 2018).

Thus, for the incorporation of new plant species into the cropping systems, the response of the crop to the physical alterations of the soil must be considered, to ensure adaptability to the system and the best way of utilizing it. An alternative crop to the Brazilian agroecosystem is safflower (Carthamus tinctorius L.) (Galant et al., 2015).

Although little cultivated in Brazil, safflower is a promising crop for the Brazilian Cerrado. Oilseed has a high oil content in its seeds, with applications in industry as well as for food and feed. Due to its ecophysiology, safflower may be a viable option for second crop cultivation in the State of Mato Grosso (Bonfim-Silva et al., 2015). Therefore, an in-depth study of the response of safflower genotypes to the physical alteration of the soil for this region is necessary, aiming at a better crop recommendation to ensure that the potential of the crop is explored.

Table 1. Granulometric characterization and chemical analysis of the 0.0 to $0.2 \mathrm{~m}$ layer of the collected soil. Rondonópolis - MT, 2014

\begin{tabular}{|c|c|c|c|c|c|c|c|c|c|c|c|c|c|}
\hline \multirow{3}{*}{$\frac{\mathrm{pH}}{\mathrm{CaCl}_{2}}$} & Sand & Silt & Clay & $\mathrm{P}$ & K & $\mathrm{Ca}$ & $\mathrm{Mg}$ & $\mathrm{H}$ & $\mathrm{Al}$ & BS & CEC & $V$ & O.M. \\
\hline & ------- & $\mathrm{g} \mathrm{kg}$ & - & $\mathrm{mg}$ & $d^{-3}$ & & & $\mathrm{cmo}$ & $\mathrm{dm}^{-3}$ & - & & $\%$ & $\mathrm{~g} \mathrm{dm}^{-3}$ \\
\hline & 423 & 133 & 444 & 1.4 & 23 & 0.4 & 0.2 & 5.4 & 0.8 & 0.7 & 6.8 & 9.7 & 27.1 \\
\hline
\end{tabular}

Thereafter, liming was performed to increase the base saturation to $60 \%$. After the procedure, the soil was packed in plastic bags for reaction. For plant fertilization, $200 \mathrm{mg}$ $\mathrm{dm}^{-3}$ of nitrogen in the form of urea, $150 \mathrm{mg}$ $\mathrm{dm}^{-3}$ of phosphorus $\left(\mathrm{P}_{2} \mathrm{O}_{5}\right)$ in the form of single superphosphate and $200 \mathrm{mg} \mathrm{dm}^{-3}$ of potassium $\left(\mathrm{K}_{2} \mathrm{O}\right)$ in the form of potassium chloride were added, according to the recommendation of Bonfim-Silva et al. (2015) for safflower cultivation.
The objective of this study was to evaluate the phytometric components and dry mass production of safflower genotypes submitted to different soil densities in Oxisol from the Cerrado.

\section{Materials and Methods}

Ten safflower genotypes were submitted to soil compaction (levels of soil density obtained by means of artificial compaction), cultivated in a protected environment at the Federal University of Mato Grosso - UFMT, Rondonópolis Campus, between April and July 2015. The mean temperature and relative humidity during the period were $28.4^{\circ} \mathrm{C}$ and $67.8 \%$, respectively.

The study design was completely randomized, consisting of ten safflower genotypes and five soil densities $\left(1.0,1.2,1.4\right.$, and $\left.1.8 \mathrm{Mg} \mathrm{m}^{-3}\right)$ with four replications, totaling 200 experimental units. Soil density levels were defined from the normal Proctor test in the laboratory so that the highest density tested $\left(1.8 \mathrm{Mg} \mathrm{m}^{-3}\right)$ is the upper limit for this soil and the optimum moisture for compaction is $16 \%$ based on mass.

Initially, the soil was collected from a Cerrado natural vegetation area in the 0.0 to $0.2 \mathrm{~m}$ depth layer, and this was sieved in a 4 $\mathrm{mm}$ mesh for the removal of vegetal material (mainly roots) and the soil was homogenized, to fill the experimental units. The soil of the area was classified as Oxisol, according to EMBRAPA (2013). Table 1 presents the results of the collected soil analysis.
For the supply of micronutrient demand, $15 \mathrm{mg}$ $\mathrm{dm}^{-3}$ of FTE BR 12 was applied, with a minimum guarantee of $9 \% \mathrm{Zn} ; 1.8 \%$ B; $0.8 \%$ Cu; $2 \%$ Mn; $3.5 \%$ Fe; and $0.1 \%$ Mo.

Each experimental unit was composed of a PVC (Polyvinyl chloride) vessel with a diameter of $200 \mathrm{~mm}$ and a height of $300 \mathrm{~mm}$, making a volume of $9.42 \mathrm{dm}^{3}$. They were sectioned transversely at $100 \mathrm{~mm}$ (Figure 1), to obtain the desired density in each layer of soil. The three rings 
were fixed by means of adhesive tape and one of its ends was covered by a polyethylene screen (1 mm thick), to prevent loss of soil. After filling with soil, the experimental units were conditioned on a plastic support of $300 \mathrm{~mm}$.

The treatments were applied to the central layer of each plot. The outer layers (upper and lower) maintained a density of 1.0 $\mathrm{Mg} \mathrm{m}^{-3}$. Soil compression to the desired density was carried out with the aid of a hydraulic press
Bovenau mark - model P15ST. The soil volume required to fill each ring at its respective densities was obtained using Eq. 1:

$$
\rho_{s}=\frac{M_{D S}}{V_{T}}
$$

where:

ps - soil density $\left(\mathrm{kg} \mathrm{dm}^{-3}\right) ; M_{D S}$ - Mass of dry soil $(\mathrm{kg})$ and $\mathrm{V}_{\mathrm{T}}$ - Total ring volume $\left(3.14 \mathrm{dm}^{-3}\right)$.

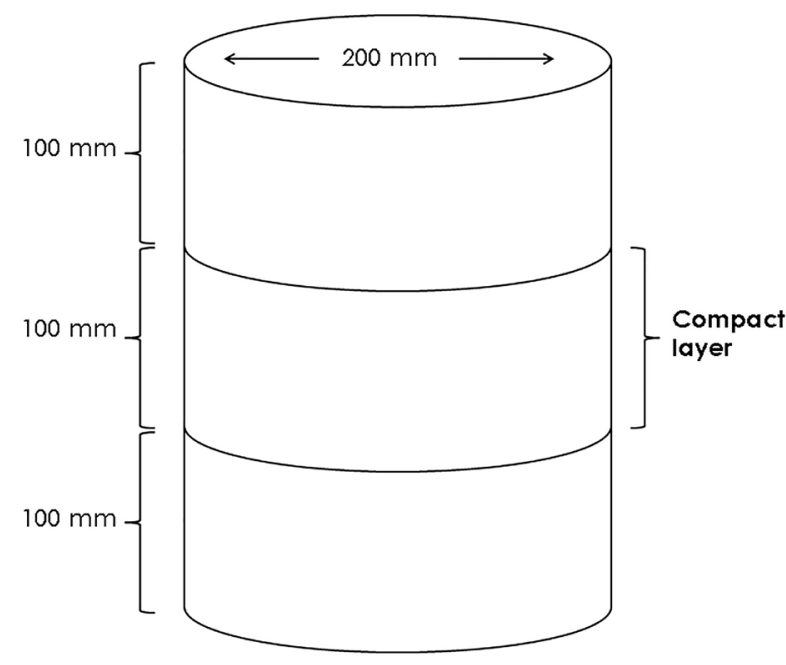

Figure 1. Representation of an experimental unit and its three layers of soil.

Ten safflower genotypes (PI237538; PI248385; PI250196; PI301049; PI305173; PI305205: PI306596; PI306603; PI560202 and Pl613366) were provided by the Mato Grosso Cotton Institute - IMA. Twenty (20) seeds were seeded per pot to ensure emergence in all plots. The soil was irrigated through the surface until the establishment of the plants (15 days). From this moment, the water was provided by capillarity to provoke the need in the plants to deepen the roots against the compacted layer (Silva et al., 2006). Soil moisture was maintained below the $25 \mathrm{kPa}$ soil moisture tension and was measured using Irrigas (Calbo and Silva, 2005), a device widely used for irrigation management mainly in vegetables. When tension was reached, water was applied freely via capillarity, so that water was not a limiting factor for the growth and development of safflower plants. After the emergence of the plants, three thinnings were performed at 5, 7 and 15 days after emergence, in which ten, six and two plants were left in each pot at the end of the third thinning, respectively.
As a phytosanitary treatment for the prevention and control of fungal diseases (mainly of the genus Alternaria), fungicide/bactericide was used with contact action of the inorganic chemical group based on Copper Oxychloride at a dose of $1.68 \mathrm{~g}$ i. a. $\mathrm{L}^{-1}$ at 15 days after sowing with new application every 15 days. Systemic fungicide was also applied to the chemical groups of Strobilurin and Triazol, at a dose of 2.0 and $0.8 \mathrm{~g}$ i. a. $\mathrm{L}^{-1}$, respectively, at 45 days after emergence with reapplication at 15-day intervals.

Periodic evaluations were performed at 30-day intervals. Thus, the data were collected at 30,60 and 90 days after the emergence of the following variables: Plant Height (PH) - measured between the soil level and the apex of the plants $(\mathrm{cm})$; Number of leaves (NL) - count of the total number of leaves of each plant; Stem diameter (STD) - measured at $2 \mathrm{~cm}$ from the soil surface by means of a digital caliper $(\mathrm{mm})$ and Shoot dry mass (SDM) - obtained by the mass of the whole aerial part except for the determined portions 
after drying in an oven at $65^{\circ} \mathrm{C}$ until constant mass.

The collected data were submitted to ANOVA and, if significant, submitted to polynomial regression analysis for soil density levels and Scott-Knott test for the genotypes. The analyses were performed using the Sisvar program (Ferreira et al., 2011), considering the 5\% probability level.

\section{Results and discussion}

Plants height

There was a statistical difference between the genotypes as a function of the evaluation days (Table 2). This fact reveals differences in the genetic characteristics of safflower genotypes from the initial phase of their development. At 30 DAE, the genotype PI237538 stood alone with the highest plant height $(32.22 \mathrm{~cm})$.

Table 2. Plant height of safflower genotypes as a function of density levels at 30,60 and 90 days after emergence. Rondonópolis - MT, 2014

\begin{tabular}{llcc}
\hline \multirow{2}{*}{ Safflower genotypes } & \multicolumn{3}{c}{ Plant height $(\mathrm{cm})$} \\
\cline { 2 - 4 } PI237538 & $30 \mathrm{DAE}$ & $60 \mathrm{DAE}$ & $90 \mathrm{DAE}$ \\
PI248385 & $32.22 \mathrm{a}$ & $83.15 \mathrm{a}$ & $93.75 \mathrm{~b}$ \\
PI250196 & $28.08 \mathrm{~b}$ & $69.83 \mathrm{~b}$ & $71.68 \mathrm{C}$ \\
PI301049 & $26.05 \mathrm{~b}$ & $69.65 \mathrm{~b}$ & $112.28 \mathrm{a}$ \\
PI305173 & $28.28 \mathrm{~b}$ & $87.13 \mathrm{a}$ & $103.73 \mathrm{a}$ \\
PI305205 & $25.83 \mathrm{~b}$ & $80.25 \mathrm{a}$ & $105.50 \mathrm{a}$ \\
PI306596 & $30.33 \mathrm{~b}$ & $83.65 \mathrm{a}$ & $87.35 \mathrm{~b}$ \\
PI306603 & $29.83 \mathrm{~b}$ & $78.91 \mathrm{a}$ & $91.50 \mathrm{~b}$ \\
PI560202 & $26.48 \mathrm{~b}$ & $70.80 \mathrm{~b}$ & $94.18 \mathrm{~b}$ \\
PI613366 & $28.49 \mathrm{~b}$ & $78.03 \mathrm{a}$ & $94.13 \mathrm{~b}$ \\
Mean & $25.93 \mathrm{~b}$ & $66.08 \mathrm{~b}$ & $113.55 \mathrm{a}$ \\
Significance & 28.45 & 76.78 & 96.76 \\
CV (\%) & $* * *$ & $* *$ & $*$ \\
\hline Means followed by the same letter in the column belongs to the same group according to Scott-Knott test at 5\% of probability ***,**significant at 0.1\% \\
and 1 \% probability, respectively. Rondonópolis - MT, 2014. CV - coefficient of variation.
\end{tabular}

At the beginning of the growth of some safflower genotypes, at $60 \mathrm{DAE}$, it was possible to observe two groups that presented higher heights (PI237538, PI301049, PI305173, PI305205, PI306596, and PI560202) followed by the second group with lower heights (PI248385, PI250196, PI306603 and Pl613366).

In the evaluation performed at $90 \mathrm{DAE}$, $90 \%$ of the experimental units were flowered, and three distinct groups were formed. The first group with an average height of $108.77 \mathrm{~cm}$, was formed by the highest plants (PI250196,

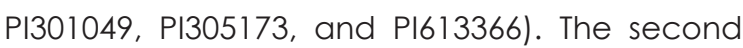
group (PI237538, PI305205, PI306596, PI306603, $\mathrm{PI560202)}$ in which the height averages ranged from 87.35 to $94.18 \mathrm{~cm}$, followed by the third group, formed only by the genotype $\mathrm{Pl} 248385$ with a mean height of $78 \mathrm{~cm}$. It should be noted that genotype $\mathrm{Pl} 1613366$ presented only $40 \%$ of its flowering experimental units, due to the fungal attack, which occurred with greater severity in this genotype, even with the application of fungicides in all treatments and genotypes.

These results show a significant difference in the plant height of safflower genotypes, which is closely related to the genetic characteristics of safflower (Figure 2). The height of safflower plants was influenced by soil density levels alone. It was observed that this variable adjusted to the linear regression model for the evaluation performed at 30 DAE, with a reduction in plant height equivalent to $45.44 \%$, between the lowest and highest density levels (Figure 2A).

According to Gerhardt (2014), reported that plant height is a very important characteristic to be analyzed in the selection of genotypes, because very short plants make mechanized harvesting difficult, and very tall plants are more prone to bedding in the field.

For the evaluations performed at 60 and $90 \mathrm{DAE}$, there was an adjustment to the quadratic regression model, with higher heights (91.14 and $112.33 \mathrm{~cm}$ ) at soil densities of 1.0 and $1.17 \mathrm{Mg} \mathrm{m}^{-3}$ (Figure $2 \mathrm{~B}$ and $2 \mathrm{C}$ ). These results show that the plant height of safflower genotypes is influenced by different soil densities.

Silva et al. (2006) when evaluating the growth of the aerial part of cotton plants 
(A)

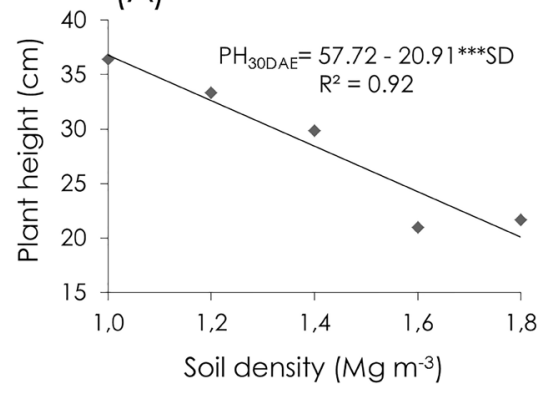

(B)

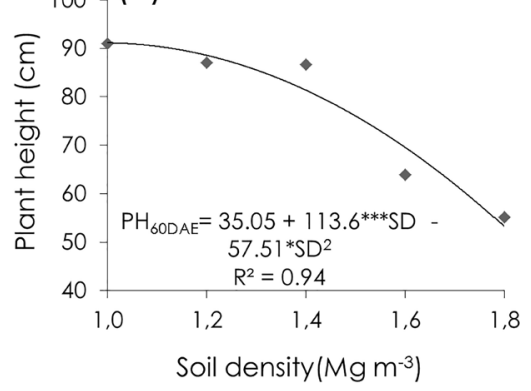

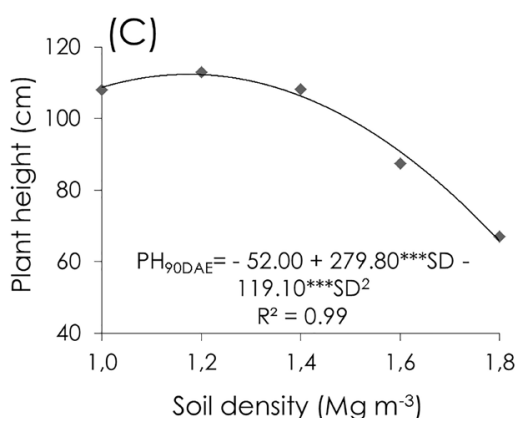

Figure 2. Plant height of safflower as a function of soil density at 30 (A), 60 (B) and 90 (C) days after emergence. PH - Plant height; SD - Soil density. ${ }^{* * *}$ Significant at $0.1 \%$ probability. Rondonópolis - MT, 2014

(Gossypium hirsutum L.), Marandu grass (Brachiaria brizantha), maize (Zea mays) and soybean (Glycine max L.) cultivated in pot, submitted to compaction levels of Oxisol, found an increase in height near soil density of $1.2 \mathrm{Mg} \mathrm{m}^{-3}$.

Larger densities provided a decrease in the height of the studied plants. Freddi et al. (2009), also verified a reduction in the height of maize plants, cultivated in Oxisol of medium texture and Oxisol of clay texture with the increase of soil density.

Compacted soils generally show serious reductions in root growth and total soil volume, so that shoot growth and development is significantly affected by this fact. Recent research has indicated a reduction of up to $94.1 \%$ of root length in safflower plants in soil with high resistance to penetration (4 MPa) after 10 days of growth (Gao et al., 2016).

Thus, the sustenance, absorption of water and nutrients are compromised, also there is increased susceptibility to water deficits, due to the concentration of roots in the soil surface layer and the low volume of soil that reduces the availability of water, in periods of drought.

\section{Number of leaves}

For the number of leaves, there was no significant interaction between safflower genotypes and soil densities in the evaluations performed at 30 and 60 days after plant emergence (DAE) (Table 3). These results show that, for the evaluated genotypes, the soil density exerts a significant influence on the number of leaves until the beginning of the flowering of safflower plants.

It can be observed that in the safflower genotypes there was a reduction in the number of leaves with increased levels of soil density, and for the evaluations performed at 30 and $60 \mathrm{DAE}$, the number of leaves was described by the linear regression model (Figure 3A and 3B).

These results demonstrate that the increase in soil density influences the reduction in the number of safflower leaves. In a study by Bonfim-Silva et al. (2011) in wheat plants (Triticum aestivum L.), the authors concluded that the densities of an Oxisol from the same area of the present study may interfere with the availability of nutrients to the roots, contributing negatively to the absorption of nutrients by reducing leaf production. Higher soil densities also lead to a reduction in the volume of soil explored by the roots and, consequently, result in decreased availability of water and nutrients in the soil solution. 
Table 3. Number of leaves of safflower genotypes as a function of density levels at 30 and 60 days after emergence. Rondonópolis - MT, 2014.

\begin{tabular}{|c|c|c|}
\hline \multirow{2}{*}{ Safflower genotypes } & \multicolumn{2}{|c|}{ Leaves $\left(n^{\circ}\right.$ pot $\left.^{-1}\right)$} \\
\hline & $30 \mathrm{DAE}$ & $60 \mathrm{DAE}$ \\
\hline PI237538 & $29.55 \mathrm{~b}$ & $162.20 \mathrm{a}$ \\
\hline PI248385 & $34.35 \mathrm{a}$ & $190.25 a$ \\
\hline PI250196 & $26.90 \mathrm{~b}$ & $116.25 \mathrm{~b}$ \\
\hline PI301049 & $32.45 \mathrm{a}$ & $165.40 \mathrm{a}$ \\
\hline PI305173 & $26.25 \mathrm{~b}$ & $152.25 \mathrm{a}$ \\
\hline PI305205 & $29.80 \mathrm{~b}$ & $179.75 \mathrm{a}$ \\
\hline PI306596 & $34.30 \mathrm{a}$ & $126.60 \mathrm{~b}$ \\
\hline PI306603 & $37.20 \mathrm{a}$ & $143.70 \mathrm{~b}$ \\
\hline PI560202 & $29.65 \mathrm{~b}$ & $115.05 \mathrm{~b}$ \\
\hline Pl613366 & $30.40 \mathrm{~b}$ & $125.40 \mathrm{~b}$ \\
\hline Mean & 31.09 & 147.69 \\
\hline Significance & $* * *$ & $* * *$ \\
\hline CV (\%) & 23.09 & 32.22 \\
\hline
\end{tabular}

(A)

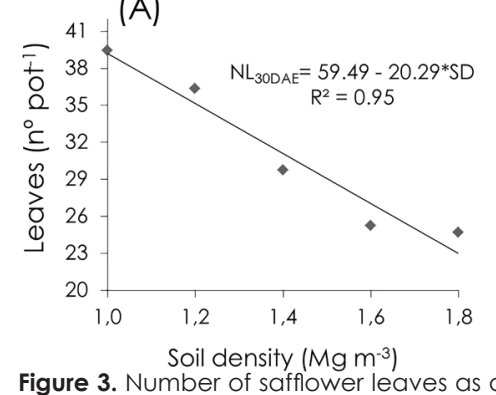

(B)

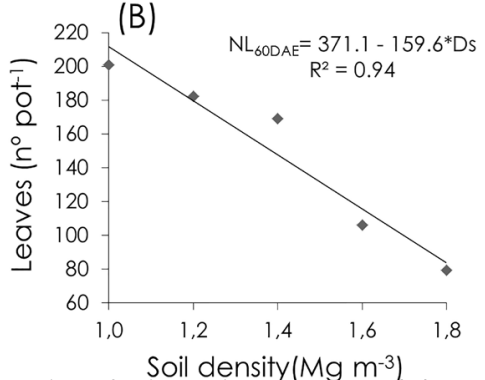

Figure 3. Number of safflower leaves as a function of soil density levels at 30 (A) and 60 (B) DAE. NL - Number of leaves; SD - Soil Density. * Significant at 5\% probability. Rondonópolis - MT, 2014.

Ohland et al. (2014), also observed that the increase in density levels in Oxisol, influenced the number of safflower and jatropha leaves, with quadratic effect as a function of soil density levels, up to a density of $1.26 \mathrm{Mg} \mathrm{m}^{-3}$.

In the evaluation performed at 90 days after emergence, the number of leaves showed significant interaction between safflower genotypes and soil densities (Table 4).

Safflower genotypes PI237538 and PI301049, fit the quadratic regression model as a function of soil density (Figure 4A and 4C). Thus, they demonstrate that the soil densities interfere negatively with the number of leaves of the safflower genotypes studied.

In the genotype PI301049, it was observed that at a soil density of $1.22 \mathrm{Mg} \mathrm{m}^{-3}, 453$ leaves were produced, for the genotype PI237538 the best yield was found at $1.25 \mathrm{Mg} \mathrm{m}^{-3}$ soil density with 389 leaves (Figure 4).

Fagundes et al. (2014), when studying soil compaction by means of density, in the
Oxisol (clay texture) of the Cerrado with three sugarcane cultivars, found that the highest number of leaves was recorded at 93 DAE, in soil density of $1.30 \mathrm{Mg} \mathrm{m}^{-3}$.

The genotypes PI248385, PI305173, PI305205, PI306596, PI306603 and PI613366 were adjusted to the linear regression model with a mean reduction of $70.42 \%$ between the lowest soil density $\left(1.0 \mathrm{Mg} \mathrm{m}^{-3}\right)$ and the highest soil density (1.8 $\mathrm{Mg} \mathrm{m}^{-3}$ ) (Figure 4B, 4D, 4E, 4F, 4G and 4H). The genotypes $\mathrm{PI} 248382$ and $\mathrm{PI} 560202$ did not present a significant difference in the number of leaves and soil density in the evaluation performed at 90 DAE.

\section{Stem diameter}

For stem diameter, there was no significant interaction between genotypes and soil density levels. At 30, 60 and 90 DAE, genotypes PI250196 and PI613366 presented the best results for stem diameter (Table 5).

At $30 \mathrm{DAE}$, the stem diameter variable 
Table 4. Number of leaves of safflower genotypes as a function of soil density levels at 90 days after emergence. Rondonópolis - MT, 2014.

\begin{tabular}{|c|c|c|c|c|c|c|c|c|c|c|}
\hline \multirow{2}{*}{$\begin{array}{l}\text { Soil density } \\
\mathrm{Mg} \mathrm{m}^{-3}\end{array}$} & \multicolumn{10}{|c|}{ Safflower genotypes Leaves $\left(\mathrm{n}^{\circ}\right.$ pot $\left.^{-1}\right)$} \\
\hline & $\mathrm{Pl} 237538$ & $\mathrm{PI} 248385$ & $\mathrm{PI} 250196$ & PI301049 & PI305173 & PI305205 & PI306596 & PI306603 & PI560202 & $\mathrm{Pl} 613366$ \\
\hline 1.0 & 302 B & $486 \mathrm{~A}$ & $175 B$ & $396 \mathrm{~A}$ & $335 \mathrm{~A}$ & $391 \mathrm{~A}$ & $473 \mathrm{~A}$ & $355 \mathrm{~A}$ & $250 \mathrm{~B}$ & $235 B$ \\
\hline 1.2 & $433 \mathrm{~A}$ & $388 \mathrm{~A}$ & $169 \mathrm{C}$ & $437 \mathrm{~A}$ & $306 \mathrm{~B}$ & $516 \mathrm{~A}$ & $321 \mathrm{~B}$ & $381 \mathrm{~A}$ & $224 \mathrm{C}$ & $343 B$ \\
\hline 1.4 & $419 \mathrm{~A}$ & $319 \mathrm{~B}$ & $185 \mathrm{~B}$ & $491 \mathrm{~A}$ & $170 \mathrm{~B}$ & $280 \mathrm{~B}$ & $280 \mathrm{~B}$ & $287 \mathrm{~B}$ & $192 B$ & $250 \mathrm{~B}$ \\
\hline 1.6 & $152 \mathrm{~A}$ & $159 \mathrm{~A}$ & $135 \mathrm{~A}$ & $219 \mathrm{~A}$ & $232 \mathrm{~A}$ & $216 \mathrm{~A}$ & $203 \mathrm{~A}$ & $261 \mathrm{~A}$ & $197 \mathrm{~A}$ & $195 \mathrm{~A}$ \\
\hline 1.8 & $151 \mathrm{~A}$ & $94 \mathrm{~A}$ & $64 \mathrm{~A}$ & $131 \mathrm{~A}$ & $92 \mathrm{~A}$ & $137 \mathrm{~A}$ & $75 \mathrm{~A}$ & $142 \mathrm{~A}$ & $132 \mathrm{~A}$ & $121 \mathrm{~A}$ \\
\hline Significance & $* *$ & & & & & & & & & \\
\hline CV (\%) & 37 & & & & & & & & & \\
\hline
\end{tabular}

Means followed by the same letter in the column belongs to the same group according to Scott-Knott test at $5 \%$ of probability. **Significant at 1 \% probability. Rondonópolis - MT, 2014. CV - coefficient of variation.
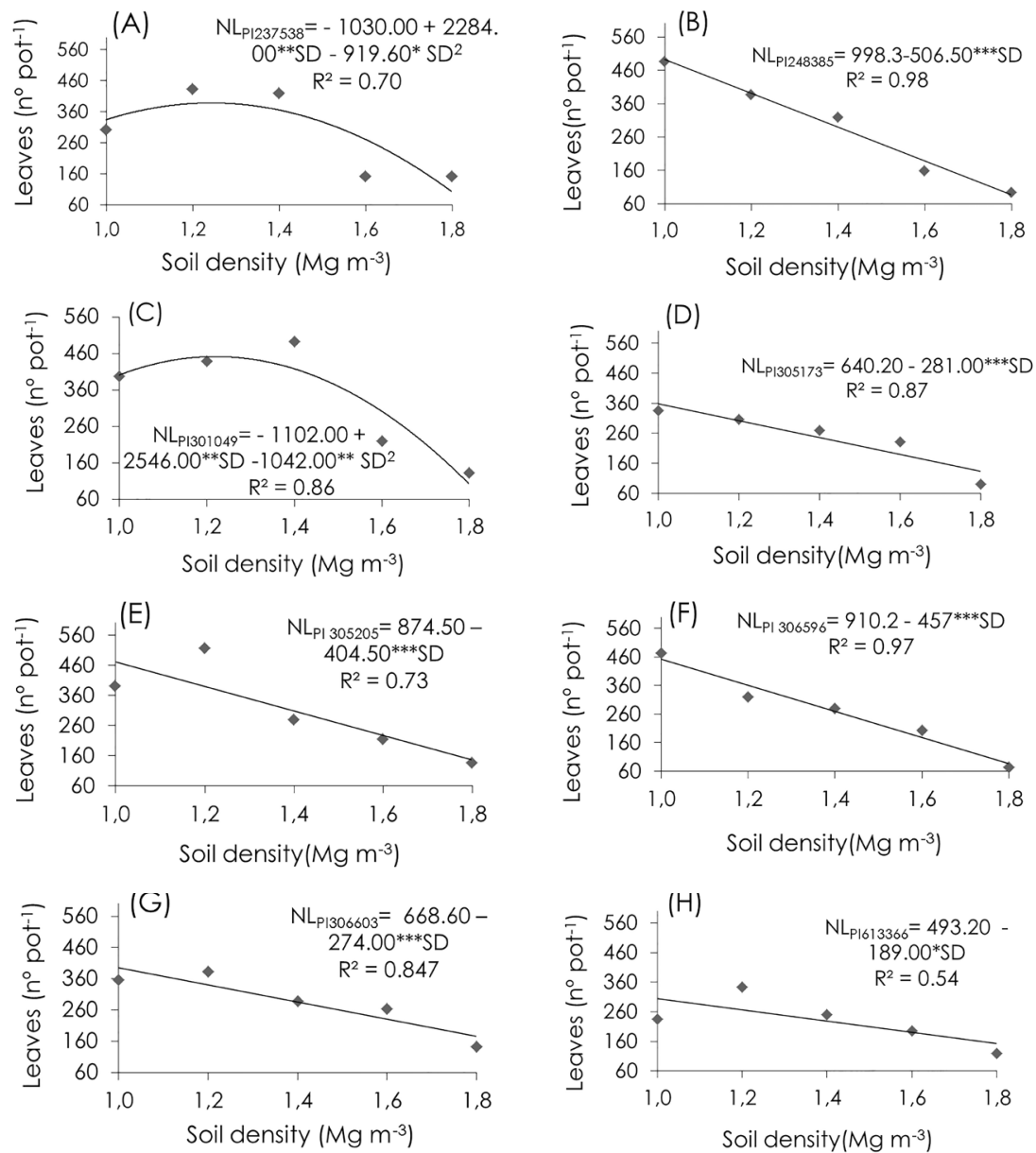

Figure 4. Number of safflower leaves as a function of soil density levels at 90 days postemergence, PI237538 (A), PI248385 (B), PI301049 (C), PI305173 (D), PI305205 (E), PI306596 (F), PI306603 (G) and PI613366 (H). NL - Number of leaves; SD - Soil Density. ${ }^{* * *},{ }^{* *},{ }^{*}$ Significant at $0.1 \%, 1 \%$ and $5 \%$ probability, respectively. Rondonópolis - MT, 2014

fitted to the linear regression model (Figure 5A). Thus, it can be observed that with increased soil density, there is a decrease in stem diameter of $5.96 \mathrm{~mm}$ between the lowest and the highest density levels, a reduction of $51.73 \%$. For the evaluations performed at 60 and $90 \mathrm{DAE}$, the variable was adjusted to the quadratic regression model with the largest diameter (12.08 and $11.85 \mathrm{~mm}$ ) at densities of 1.17 and $1.18 \mathrm{Mg} \mathrm{m}^{-3}$, respectively (Figure $5 \mathrm{~B}$ and $5 \mathrm{C}$ ).

The genotypes showed a significant reduction in stem diameter with increasing soil density, suggesting that the crop is sensitive to soil compaction for this variable. Plants with a thick stem may result in lodging during the fruiting phase since larger diameter stems offer better support, as well as a probable reduction in the height of the plants, which may affect harvesting. 
Table 5. Stem diameter of safflower genotypes as a function of density levels at 30, 60 and 90 days after emergence. Rondonópolis - MT, 2014

\begin{tabular}{|c|c|c|c|}
\hline \multirow{2}{*}{ Safflower genotypes } & \multicolumn{3}{|c|}{ Stem diameter (mm) } \\
\hline & $30 \mathrm{DAE}$ & $60 \mathrm{DAE}$ & $90 \mathrm{DAE}$ \\
\hline $\mathrm{PI} 237538$ & $6.92 \mathrm{~b}$ & $8.84 \mathrm{~b}$ & $9.21 \mathrm{C}$ \\
\hline $\mathrm{Pl} 248385$ & $7.47 \mathrm{~b}$ & $8.15 \mathrm{~b}$ & $7.95 \mathrm{c}$ \\
\hline $\mathrm{PI} 250196$ & $12.07 \mathrm{a}$ & $12.76 \mathrm{a}$ & $12.12 \mathrm{a}$ \\
\hline $\mathrm{PI} 301049$ & $7.42 \mathrm{~b}$ & $8.84 \mathrm{~b}$ & $9.54 \mathrm{C}$ \\
\hline $\mathrm{PI} 305173$ & $8.88 \mathrm{~b}$ & $10.56 \mathrm{~b}$ & $10.62 b$ \\
\hline PI305205 & $7.62 \mathrm{~b}$ & $9.75 \mathrm{~b}$ & $9.35 \mathrm{c}$ \\
\hline $\mathrm{PI} 306596$ & $8.09 \mathrm{~b}$ & $9.33 \mathrm{~b}$ & $9.35 \mathrm{c}$ \\
\hline PI306603 & $8.52 \mathrm{~b}$ & $10.30 \mathrm{~b}$ & $10.43 b$ \\
\hline PI560202 & $7.84 \mathrm{~b}$ & $9.54 \mathrm{~b}$ & $9.28 \mathrm{c}$ \\
\hline $\mathrm{Pl} 613366$ & $10.77 a$ & $13.40 \mathrm{a}$ & $12.86 a$ \\
\hline Mean & 8.56 & 10.25 & 10.07 \\
\hline Significance & $* * *$ & $* * *$ & $* * *$ \\
\hline CV (\%) & 25.82 & 22.83 & 20.58 \\
\hline
\end{tabular}
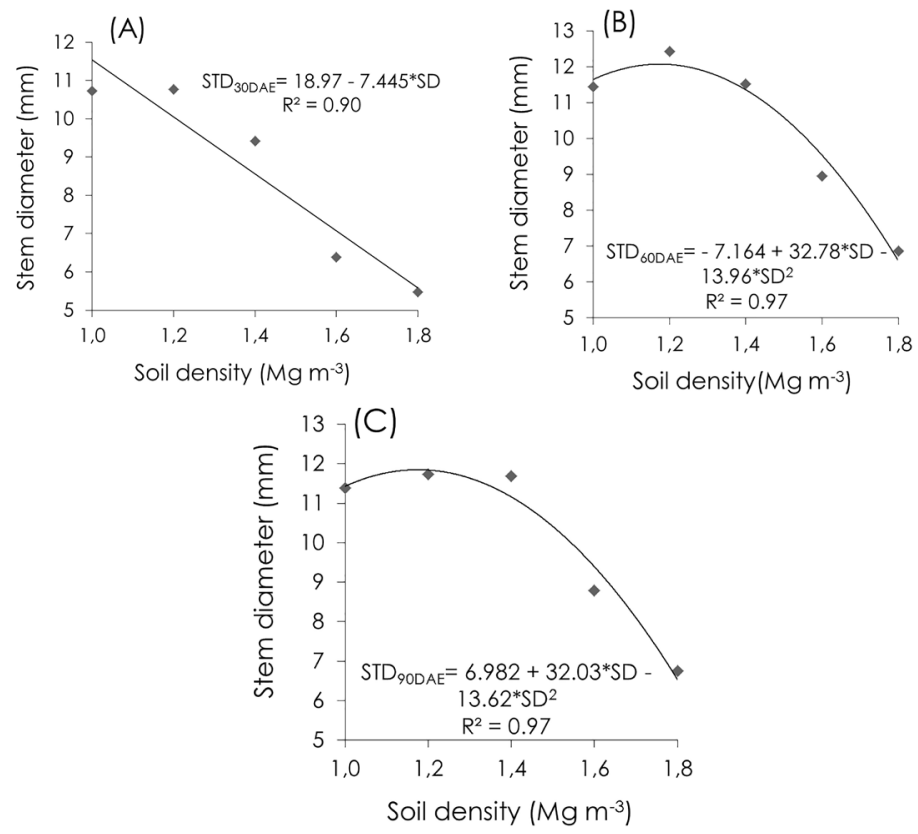

Figure 5. Safflower stem diameter as a function of soil density levels at 30 (A), 60 (B) and 90 (C) DAE. STD - stem diameter; SD - Soil Density. * Significant at 5\% probability. Rondonópolis - MT, 2014

The results observed by Silva et al. (2012) corroborate those found in this study. When evaluating the stem diameter of crambe plants, they observed a reduction in stem growth when a physical impediment was found in the soil. Therefore, interferences in the root system directly influence the aerial part (shoot) of the plant.

From the physical point of view, increased soil density, besides being an impediment to root growth, causes changes in plant water availability, aeration, and soil heat flux. These changes are predominant for proper root development of any species, some of which are more adaptable to these alterations (Lima et al., 2007). However, the negative influence on water availability results in a decrease in the absorption of water and nutrients by plants, since they are absorbed via soil solution, resulting in lower growth and development (Taiz et al., 2017). Soils with reduced aeration can cause serious damage to plant metabolism. In soil oxygen deficiency situations (anoxia or hypoxia), the absorption and transport of water and nutrients can be impeded, due to the closure of the aquaporins of root cells, so that the permeability of the root to water is reduced 
and the absorption and transportation are compromised (Buchanan et al., 2015).

In a research on the effect of compacting a dystrophic Red Latosol (clay texture) on dwarf pigeon pea, adjustment to the linear regression model was observed at 33 days after emergence of the plants, for stem diameter, with a reduction of $38.49 \%$ due to the increase in soil density levels (Farias et al., 2013).

Evaluating the optimum water range in Oxisol (very clayey) in the no-tillage systems in the State of Paraná, Tormena et al. (2007) found that densities above $1.25 \mathrm{Mg} \mathrm{m}^{-3}$ significantly decrease aeration porosity and increase penetration resistance. For Valicheski et al. (2012), significant reductions in the dry matter yield of turnip and black oat were observed at soil density above $1.34 \mathrm{Mg} \mathrm{m}^{-3}$.

Thus, it is evident that soil densities above 1.2 to $1.3 \mathrm{Mg} \mathrm{m}^{-3}$ cause physical impediments to root growth and development of various crops. It is also assumed that, besides the physical impediment to growth, densities above the above-mentioned range, especially in clay soils, cause detriment to the aeration of the root system and water availability, which will compromise the growth and development of vegetative and reproductive structures of the safflower plant.

Research evidenced a greater susceptibility to compaction of a clayey Oxisol than a clay-sandy loam at humidity close to the field capacity in response to agricultural traffic. They also verified a reduction in the pore volume and pore diameter, altering the water retention energy in the soil (Lima et al., 2017).

\section{Shoot dry mass}

For the shoot dry mass, there was a significant interaction between the genotypes and soil densities (Table 6 and Figure 6 ).

Table 6. Shoot dry mass of safflower genotypes as a function of soil density levels at 90 days after emergence. Rondonópolis - MT, 2014.

\begin{tabular}{|c|c|c|c|c|c|c|c|c|c|c|}
\hline \multirow{2}{*}{$\mathrm{SD}\left(\mathrm{Mg} \mathrm{m}^{-3}\right)$} & \multicolumn{10}{|c|}{ Shoot dry mass of safflower genotypes ( $\mathrm{g} \mathrm{vaso}^{-1}$ ) } \\
\hline & $\mathrm{Pl} 237538$ & $\mathrm{Pl} 248385$ & $\mathrm{PI} 250196$ & PI301049 & PI305173 & PI305205 & PI306596 & $\mathrm{PI} 306603$ & $\mathrm{PI} 560202$ & $\mathrm{Pl} 613366$ \\
\hline 1.0 & $68 \mathrm{C}$ & $50 \mathrm{C}$ & $83 \mathrm{~B}$ & $63 \mathrm{C}$ & $63 \mathrm{C}$ & $66 \mathrm{C}$ & $66 \mathrm{C}$ & $59 \mathrm{C}$ & $52 \mathrm{C}$ & $111 \mathrm{~A}$ \\
\hline 1.2 & $65 \mathrm{~B}$ & $48 \mathrm{~B}$ & $85 \mathrm{~A}$ & $77 \mathrm{~A}$ & $74 \mathrm{~A}$ & $67 \mathrm{~B}$ & $66 \mathrm{~B}$ & $59 \mathrm{~B}$ & $60 \mathrm{~B}$ & $92 \mathrm{~A}$ \\
\hline 1.4 & $59 \mathrm{~B}$ & $37 \mathrm{~B}$ & $85 \mathrm{~A}$ & $71 \mathrm{~A}$ & $72 \mathrm{~A}$ & $65 \mathrm{~B}$ & $66 \mathrm{~B}$ & $55 \mathrm{~B}$ & $60 \mathrm{~B}$ & $83 \mathrm{~A}$ \\
\hline 1.6 & $18 \mathrm{~B}$ & $14 B$ & $61 \mathrm{~A}$ & $34 \mathrm{~B}$ & $69 \mathrm{~A}$ & $22 \mathrm{~B}$ & $28 B$ & $38 \mathrm{~B}$ & $32 \mathrm{~B}$ & $60 \mathrm{~A}$ \\
\hline 1.8 & $13 \mathrm{~A}$ & $12 \mathrm{~A}$ & $23 \mathrm{~A}$ & $22 \mathrm{~A}$ & $12 \mathrm{~A}$ & $15 \mathrm{~A}$ & $9 \mathrm{~A}$ & $23 \mathrm{~A}$ & $15 \mathrm{~A}$ & $14 \mathrm{~A}$ \\
\hline Significance & $*$ & & & & & & & & & \\
\hline CV (\%) & $\frac{34.04}{\text { same lette }}$ & & & & & & & & & \\
\hline
\end{tabular}

At soil density of $1.0 \mathrm{Mg} \mathrm{m}^{-3}$, the genotype Pl613366 showed the highest shoot dry mass (111 $\mathrm{g}$ pot $\left.^{-1}\right)$, followed by genotype PI250196 (83g pot $^{-1}$ ), being the third group formed by the other genotypes that did not differ statistically from each other, presenting a mean shoot dry mass of $60.88 \mathrm{~g} \mathrm{pot}^{-1}$.

For the density $1.2 \mathrm{Mg} \mathrm{m}^{-3}$, two groups were formed, the ones that produced the greatest quantity of dry mass PI250196, PI301049, $\mathrm{Pl} 305173$ and $\mathrm{Pl} 613366$ and the one with lower dry mass production genotypes PI237538, PI248385, $\mathrm{Pl} 305205, \mathrm{PI} 306596, \mathrm{PI} 306603$, and PI560202.

In the soil density $1.4 \mathrm{Mg} \mathrm{m}^{-3}$, significant differences were observed among the genotypes, evidencing that the genotypes $\mathrm{PI} 250196, \mathrm{PI} 301049, \mathrm{PI} 05173$, and Pl613366 are less sensitive to this level of soil density when compared to the second group formed by the genotypes PI237538, PI248385, PI305205, PI306596, $\mathrm{PI} 306603$ and PI560202.

For the density $1.6 \mathrm{Mg} \mathrm{m}^{-3}$, three genotypes PI250196, PI305173 and Pl613366 stood out with an average of $63.33 \mathrm{~g} \mathrm{pot}^{-1}$ of shoot dry mass. In the other genotypes, PI237538, $\mathrm{PI} 248385, \mathrm{PI} 301049, \mathrm{PI} 305205, \mathrm{PI} 306596, \mathrm{PI} 306603$ and PI560202 a mean of $26.57 \mathrm{~g} \mathrm{pot}^{-1}$ was observed. This corresponds to a difference of $58.05 \%$ between the two groups, showing that some of the studied genotypes present a better developmental adaptation in the density of 1.6 $\mathrm{Mg} \mathrm{m}^{-3}$. However, for soil density of $1.8 \mathrm{Mg} \mathrm{m}^{-3}$, there was no significant difference between the genotypes.

The genotypes PI237538, PI248385, $\mathrm{Pl} 305205, \mathrm{Pl} 306603$ and Pl613366 presented an 


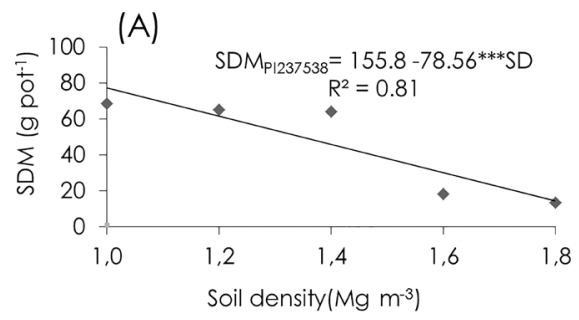

(B)
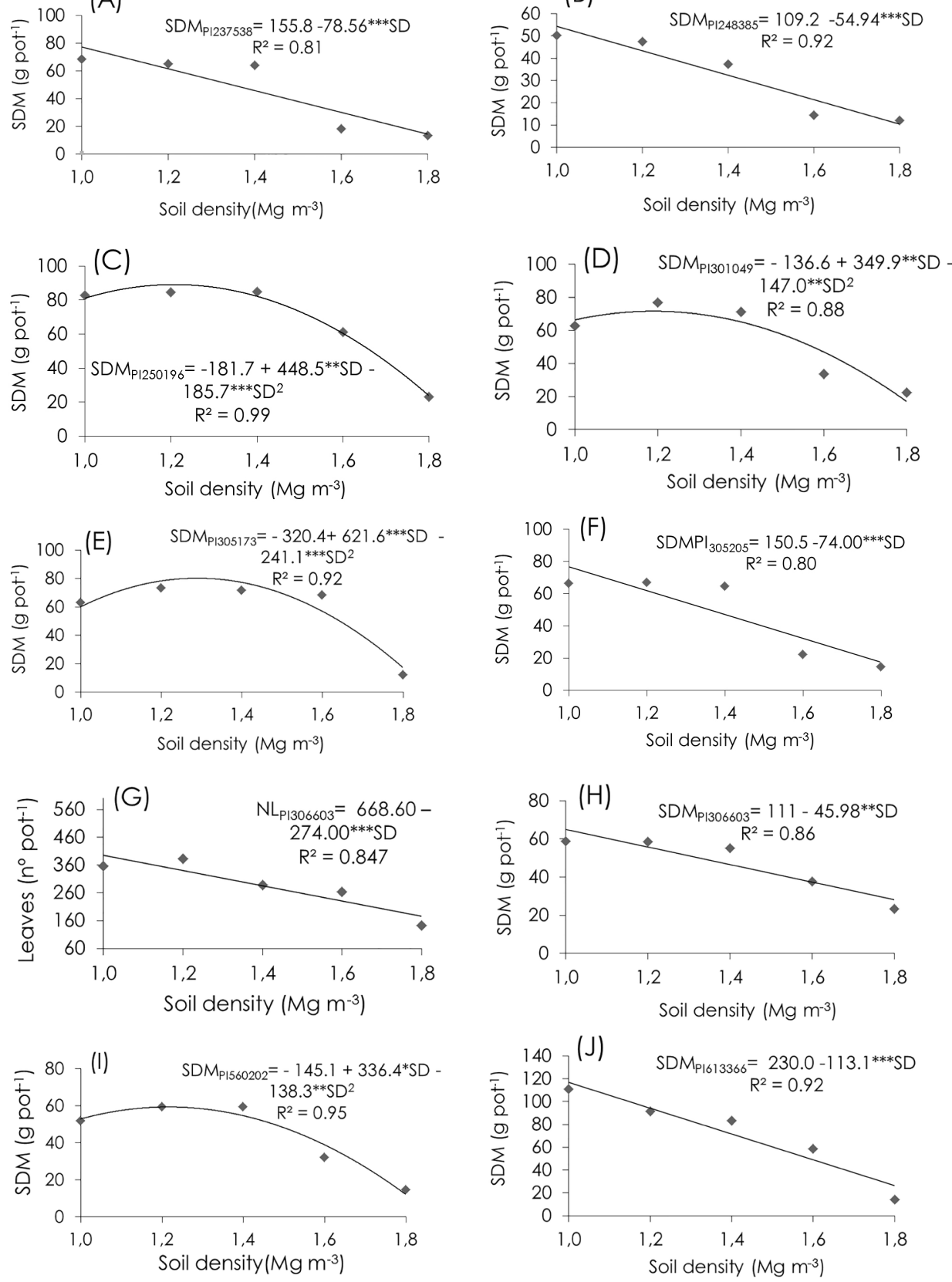

Figure 6. Shoot dry mass of safflower as a function of the levels of soil density, PI237538 (A), PI248385 (B), PI250196 (C), PI301049 (D), PI305173 (E), PI305205 (F), PI306596 (G), PI306603 (H), PI560202 (I) e PI613366 (J). SDM - Shoot dry mass; SD - Soil Density. ${ }^{* * *},{ }^{* *},{ }^{*}$ Significant at $0.1 \%, 1 \%$ and 5\% probability, respectively. Rondonópolis - MT, 2014.

adjustment to the linear regression model with increasing soil density (Figure 6A, 6B, 6F, 6H, and 6J). It can be observed that there was a reduction in shoot dry mass, with an increase in soil density.

The genotypes PI250196, PI301049, $\mathrm{PI} 305173, \mathrm{PI} 306596$, and PI560202 conformed to the quadratic regression model, showing that they are more tolerant to increasing soil density (Figure 6C, 6D, 6E, 6G and 61). The genotypes developed better at densities of $1.20 ; 1.19 ; 1.28$; 1.12 and $1.22 \mathrm{Mg} \mathrm{m}^{-3}$, respectively.
Bonfim-Silva et al. (2012), when studying two cultivars of Brachiaria brizantha (cvs. Xaraés and Marandu) under four soil densities (1.0; 1.2; 1.4 and $1.6 \mathrm{Mg} \mathrm{m}^{-3}$ ), found the highest shoot dry matter yield in soil density of $1.23 \mathrm{Mg} \mathrm{m}^{-3}$, corroborating the results found in the present study.

\section{Conclusions}

Safflower genotypes presented different responses to soil density levels, with a mean 
reduction of $56.30 \%$ in all evaluated components. The number of leaves was the most affected, with a reduction of $70.42 \%$.

The safflower genotypes evaluated showed high sensitivity to growth in soil with physical impediments, except for PI250196, PI301049, PI305173 and PI305205 which are more stable about soil density variations.

The phytometric components of plant height, number of leaves and stem diameter, as well as the dry mass of safflower shoot are impaired from the mean density of $1.2 \mathrm{Mg} \mathrm{m}^{-3}$.

\section{Acknowledgments}

The authors extend their gratitude to IMA (Mato Grosso Cotton Institute) for supplying the seeds of the safflower genotypes, and UNESP (Universidade Estadual Paulista Julio de Mesquita Filho), for their support in running this experiment. The authors express gratitude to CAPES and the CNPq for funding this project.

\section{References}

Buchanan, B.B., Gruissem, W., Jones, R.L. 2015. 2 ed. Chichester: Wiley Blackwell. 1264p.

Bonfim-Silva, E.M., Anicésio, E.C.A., Silva, F.C.M., Dourado, L.G.A., Aguero, N.F. 2011. Compactação do solo na cultura do trigo em Latossolo do Cerrado. Enciclopédia Biosfera 7: $1-8$.

Bonfim-Silva, E.M., Junior Valadão, D.D., Reis, R.H.P., Campos, J.J., Scaramuzza, W.L.M.P. 2012. Estabelecimento dos Capins Xaraés e Marandu sob níveis de compactação do solo. Revista Brasileira de Engenharia Agrícola e Ambiental 32: 727-735.

Bonfim-Silva, E.M., Paludo, J.T.S., Sousa, J.V.R., Sousa, H.H.F., Silva, T.J.A. 2015. Development of Safflower Subjected to Nitrogen Rates in Cerrado Soil. American Journal of Plant Sciences 6: 21362143.

Calbo, A.G., Silva, W.L.C. 2005. Sistema Irrigas para Manejo de Irrigação: Fundamentos, Aplicações e Desenvolvimentos. 1 ed. Brasília: EMBRAPA. $174 \mathrm{p}$.

Empresa Brasileira De Pesquisa Agropecuária - EMBRAPA. 2013. Sistema brasileiro de classificação de solos. Embrapa, Brasília, Brasil. 353p.

Fagundes, E.A.A., Silva, T.J.A., Bonfim-Silva, E.M. 2014. Desenvolvimento inicial de variedades de cana-de-açúcar em Latossolo submetidas a níveis de compactação do solo. Revista Brasileira de Engenharia Agrícola e Ambiental 18: 188-193.

Farias, L.N., Bonfim-Silva, E.M., Souza, W.P., Vilarinho, M.K.C., Silva, T.J.A., Guimarães, S.L. 2013. Características morfológicas e produtivas de feijão guandu anão cultivado em solo compactado. Revista Brasileira de Engenharia Agrícola e Ambiental 17: 497-503.

Ferreira, D.F. 2011. Sisvar: A computer statistical analysis system. Ciência e Agrotecnologia 35: 1039-1042.

Freddi, O.S., Centurion, J.F., Duarte, A.P., Leonel, C.L. 2009. Compactação do solo e produção de cultivares de milho em Latossolo vermelho. I Características de planta, solo e índice S. Revista Brasileira de Ciência do Solo 33: 793-803.

Galant, N.B., Santos, R.F., Silva, M.A. 2015. Melhoramento de cártamo (Carthamus tinctorius L.). Acta Iguazu 4: 14-25.

Gao, W., Hodgkinson, L., Jin, K., Watts, C.W., Ashton, R.W., Shen, J., Ren, T., Dodd, I.C., Binley, A., Phillips, A.L., Hedden, P., Hawkesford, M.J. and Whalley, W.R. 2016. Deep Roots and Soil Structure. Plant Cell Environment 39: 1662-1668.

Genro Junior, S.A., Reinert, D.J., Reichert, J.M. 2004. Variabilidade temporal da resistência à penetração de um Latossolo argiloso sob semeadura direta com rotação de culturas. Revista Brasileira de Ciência do Solo 28: 477-484.

Gerhardt, I.F.S. 2014. Divergência genética entre acessos de cártamo (Carthamus tinctorius L.). 35p. (M. Sc. Dissertação) - Faculdade de Ciências Agronômicas - UNESP, Botucatu, Brazil.

Lima, C.L.R., Reichert, J.M., Reinert, D.J., Suzuki, L.E.A.S., Dalbianco, L. 2007. Densidade crítica ao crescimento de plantas considerando água disponível e resistência à penetração de um Argissolo Vermelho distrófico arênico. Ciência Rural 37: $1166-1169$.

Lima, R.P., Da Silva, A.P., Giarola, N.F.B., Da Silva, A.R., Rolim, M.M. 2017. Changes in soil compaction indicators in response to agricultural field traffic. Biosystems Engineering 162: 1-10.

Obour, P.B., Schonning, P., Peng, Y., Munkholm, L.A. 2017. Subsoil compaction assessed by visual evaluation and laboratory methods. Soil \& Tillage Research 173: 4-14.

Ohland, T., Lama, M.C., Frandoloso, J.F., Rampim, L., Bergmann, J.R., Cabreira, D.T. 2014. Influência da densidade do solo no desenvolvimento inicial do pinhão-manso cultivado em Latossolo Vermelho eutroférrico. Revista Ceres 61: 622-630.

Reinert, D.J., Albuquerque, J.A., Reichert, J.M., 
Andrade, M.M.C. 2008. Limites críticos de densidade do solo para o crescimento de raízes de plantas de cobertura em Argissolo Vermelho. Revista Brasileira de Ciência do Solo 32: 18051816.

Reichert, J.M., Suzuki, A.A., Reinert, D.J., Horn, R., Hakansson, I. 2009. Reference bulk density and critical degree-of-compactness for no-till crop production in subtropical highly weathered soils. Soil \& Tillage Research 102: 242-254.

Silva, G.J., Maia, J.C.S., Bianchini, A. 2006. Crescimento da parte aérea de plantas cultivadas em vaso, submetidas à irrigação subsuperficial e a diferentes graus de compactação de um Latossolo Vermelho-Escuro distrófico. Revista Brasileira Ciência do Solo 30: 31-40.

Silva, S.D., Alves, J.M., Mesquita, G.M., Leandro, W.M. 2012. Efeito da compactação do solo no desenvolvimento aéreo e radicular do pinhão manso (Jatropha curcas L.) e crambe (Crambe abyssinica Hochst). Global Science and Technology 5: 87-97.

Sivarajan, S., Maharlooei, M., Bajwa, S.G., Nowatzki, J. 2018. Impact of soil compaction due to wheel traffic on corn and soybean growth, development and yield. Soil \& Tillage Research 175: $234-243$

Taiz, L., Zeiger, E., Moller, I.M., Murphy, A. 2017. Fisiologia e desenvolvimento vegetal. 6 ed. Porto Alegre: Artmed. 858p.

Tormena, C.A., Araújo, M.A., Fidalski, J., Costa, J.M. 2007. Variação temporal do intervalo hídrico ótimo de um Latossolo Vermelho distroférrico sob sistemas de plantio direto. Revista Brasileira de Ciência do Solo 31: 211-219.

Valicheski, R.R., Grossklaus, F., Stürmer, S.L.K., Tramontin, A.L., Baade, E.S.A.S. 2012. Desenvolvimento de plantas de cobertura e produtividade da soja conforme atributos físicos em solo compactado. Revista Brasileira de Engenharia Agrícola e Ambiental 16: 969-977. 